\title{
PENGEMBANGAN E-MODUL PADA MATA PELAJARAN ADMINISTRASI SERVER BERBASIS PROJECT BASED LEARNING KELAS XI TEKNIK KOMPUTER DAN JARINGAN DI SMK NEGERI 3 SINGARAJA
}

\author{
I Wayan Wilantara Adi Kusuma', Gede Saindra Santyadiputra², I Gede Partha Sindu ${ }^{3}$ \\ Jurusan Pendidikan Teknik Informatika \\ Universitas Pendidikan Ganesha \\ Singaraja, Bali \\ Indonesia
}

e-mail: wilantaraadikusuma@gmail.com¹,gsaindras@undiksha.ac.id ${ }^{2}$, partha.sindu@undiksha.ac.id ${ }^{3}$

\begin{abstract}
Abstrak
Tujuan penelitian ini (1) Untuk menghasilkan rancangan dan mengimplementasikan hasil rancangan pengembangan e-modul pada mata pelajaran administrasi server berbasis project based learning Kelas XI Teknik Komputer dan Jaringan di SMK Negeri 3 Singaraja, (2) Untuk mengetahui respon guru dan siswa terhadap pengembangan e-modul pada mata pelajaran administrasi server berbasis project based learning Kelas XI Teknik Komputer dan Jaringan di SMK Negeri 3 Singaraja. Model pembelajaran yang diterapkan dalam pengembangan modul elektronik ini adalah model pembelajaran project based learning.

Jenis penelitian yang digunakan dalam penelitian ini adalah penelitian dan pengembangan (Research and Development) dengan model pengembangan ADDIE. Subjek penelitian ini yaitu siswa kelas XI Teknik Komputer dan Jaringan di SMK Negeri 3 Singaraja tahun ajaran 2017/2018. Untuk mengetahui respon guru dan siswa terhadap e-modul administrasi server diperoleh dengan menggunakan metode angket.

Hasil penelitian menunjukkan bahwa: (1) Hasil rancangan dan implementasi e-modul pada mata pelajaran administrasi server berbasis project based learning Kelas XI Teknik Komputer dan Jaringan di SMK Negeri 3 Singaraja dinyatakan berhasil diterapkan berdasarkan beberapa uji yang dilakukan. (2) Hasil analisis data respon guru menunjukkan bahwa, didapatkan rata-rata skor respon sebesar 43, jika dikonversikan ke dalam tabel penggolongan respon maka termasuk pada kategori positif. Sedangkan untuk respon siswa terhadap pengembangan e-modul didapatkan rata-rata skor respon sebesar 60,78 , jika dikonversikan ke dalam tabel penggolongan respon siswa termasuk pada kategori positif.
\end{abstract}

Kata-kata kunci: E-Modul, ADDIE, Administrasi Server, Project Based Learning.

\section{Abstract}

The purpose of this study (1) In order to implement the results of the E-Module Project Based Learning Model in Server Administration Basics Class XI Computer Engineering and Networks in SMK Negeri 3 Singaraja. (2) To study the response of teachers and students towards the development of EModule Project Based Learning Model in Server Administration Basics Class XI Computer Engineering and Networks in SMK Negeri 3 Singaraja developed.

The type of the research used in this study was Research and Development using ADDIE development model. The subjects of the study were the eleven grade students of Computer Engineering and Networks at SMK Negeri 3 Singaraja in academic year 2017/2018. In order to identify the teachers' and students' respond toward the e module of Network Design, questionnaire was used to obtain the data.

The results obtained shown that (1) the results of the E-Module Project Based Learning Model in Server Administration Basics Class XI Computer Engineering and Networks in SMK Negeri 3 Singaraja otherwise successfully applied by some of the tests conducted. (2) The results of the analysis show that the teacher response data, obtained an average score of response was 43 when converted into the classification table, the response included in the category of positive. As for the students' response to the development of e-modules obtained an average score of 60.78 response, if converted into a table classifying student responses included in the category of positive. 


\section{PENDAHULUAN}

Bahan ajar dapat dibuat dalam berbagai bentuk sesuai dengan kebutuhan dan karakteristik materi ajar yang disajikan. National Centre For Competency Based Training menjelaskan bahan ajar adalah segala bentuk bahan yang digunakan untuk membantu guru dan instruktur dalam melaksanakan proses pembelajaran.[1] Santyasa mengemukakan modul merupakan suatu cara pengorganisasian materi pelajaran yang memperhatikan fungsi pendidikan artinya, melalui modul suatu pembelajaran diharapkan mampu membawa peserta didik pada kompetensi dasar yang diharapkan.[2]

SMK Negeri 3 Singaraja yang memiliki lulusan yang berkompetitif dan berkualitas. SMK Negeri 3 Singaraja tetap menggunakan Kurikulum 2013. SMK Negeri 3 Singaraja memiliki sepuluh (10) kompetensi keahlian salah satu diantaranya adalah Kompetensi Keahlian Teknik Komputer dan Jaringan yang membekali siswa dengan keterampilan, pengetahuan dan sikap agar kompeten dalam komputer dan jaringan komputer. Kompetensi keahlian teknik komputer dan jaringan mempunyai beberapa mata pelajaran wajib yang harus ditempuh oleh siswa salah satunya adalah mata pelajaran administrasi server yang wajib dipelajari dan ditempuh oleh kelas XI Teknik Komputer dan Jaringan.

Berdasarkan hasil wawancara yang dilakukan dengan guru mata pelajaran administrasi server kelas XI kompetensi keahlian teknik komputer dan jaringan di SMK Negeri 3 Singaraja, diperoleh informasi bahwa kurangnya bahan ajar yang relevan dan sesuai dengan karakteristik siswa. Selain melakukan wawancara dengan guru mata pelajaran administrasi server, peneliti juga memberikan angket kepada siswa kelas XI TKJ 2 yang berjumlah 29 orang, dari angket tersebut diperoleh data bahwa ditemukan beberapa kendala. Adapun kendala yang sering terjadi dalam pembelajaran administrasi server diantaranya: 1) $(17,24 \%)$ siswa menyatakan terlalu banyak materi yang harus dicari, 2) $(10,34 \%)$ siswa menyatakan rumitnya mencari materi sendiri-sendiri sehingga siswa memerlukan suatu wadah untuk mengakses materi yang sudah tersusun lengkap khususnya mata pelajaran administrasi server; 3) kurangya kelengkapan bahan ajar, seperti $(62,07 \%)$ siswa menyatakan tidak adanya buku atau modul, materi ajar yang belum tersusun secara komperhensif serta minimnya media dan sumber belajar yang digunakan siswa sebagai bahan belajar mata pelajaran administrasi server, dan 4) $(10,34 \%)$ siswa menyatakan tanpa kendala. Selama ini sumber belajar dalam proses pembelajaran administrasi server di SMK Negeri 3 Singaraja tergantung pada materi internet, materi yang didapat oleh masing-masing siswa tidak sama serta penjelasan dari guru yang masih terbatas. Oleh karena itu, seoarang guru harus memiliki kompetensi untuk mengembangkan pembelajaran dengan menggunakan suatu bahan ajar yang lengkap, mudah dipelajari dan tersusun secara komperhensif. Salah satu bentuk bahan ajar yang dapat dikembangkan adalah modul. Seiring dengan berkembangnya teknologi informasi dan komunikasi yang saat ini sudah banyak diaplikasikan ke dalam proses pembelajaran. Salah satu contohnya adalah mengubah penyajian bahan ajar berupa modul cetak menjadi modul yang dikemas dalam format digital. Keberadaan media pembelajaran ini pada akhirnya dapat menunjang dan melengkapi peran guru sebagai satu-satunya sumber informasi bagi siswa, hal ini telah dibuktikan dari penelitian yang dilakukan oleh Adiputra, dimana hasil penelitiannya menunjukkan bahwa pengembangan e-modul melakukan instlasasi sistem operasi berbasis GUI dan Text untuk siswa kelas $\mathrm{X}$ program keahlian 
teknik komputer dan jaringan di SMK Negeri 3 Singaraja mampu menjadi sumber belajar bagi siswa.[3] Penelitian yang dilakukan oleh Adnyana, dimana hasil penelitiannya menunjukkan bahwa pengembangan modul ajar melakukan instalasi perangkat jaringan lokal untuk kelas XI program keahlian Teknik Komputer dan Jaringan di SMK Negeri 3 Tabanan mampu menjadi sumber belajar bagi siswa.[4] Modul digunakan sebagai panduan belajar siswa di sekolah maupun di rumah, sehingga dapat meningkatkan minat belajar dan meningkatkan pemahaman teori serta konsep melakukan instalasi perangkat jaringan lokal. Selain itu penelitian yang dilakukan oleh Jonias yang berjudul Pengembangan Media Pembelajaran E-Modul Terhadap Prestasi Belajar Siswa Dalam Mata Pelajaran Muatan Lokal Elektronika Di SMP N 6 Surabaya menunjukkan bahwa hasil belajar siswa yang menggunakan media pembelajaran e-modul lebih baik daripada hasil belajar siswa yang tanpa menggunakan media pembelajaran emodul.[5] Penelitian terakhir yang dilakukan oleh Satriawati tentang Pengembangan EModul Interaktif Sebagai Sumber Belajar Elektronika Dasar Kelas $X$ SMK N 3 Yogyakarta. Hasil penelitiannya menunjukkan bahwa Kualitas E-modul interaktif sebagai sumber belajar elektronika dasar di SMKN 3 Yogyakarta layak digunakan.[6]

Berdasarkan latar belakang di atas maka peneliti mengangkat judul "Pengembangan E-Modul Pada Mata Pelajaran Administrasi Server Berbasis Project Based Learning Kelas XI Teknik Komputer Dan Jaringan Di SMK Negeri 3 Singaraja" guna memberikan berbagai kemudahan serta memberikan bahan belajar yang terstruktur bagi siswa

\section{KAJIAN TEORI}

Poppy Kamalia Devi, perangkat pembelajaran merupakan suatu perangkat yang dipergunakan dalam proses belajar mengajar.[7] Sugihartono, pembelajaran merupakan setiap upaya yang dilakukan dengan sengaja oleh pendidik yang dapat menyebabkan peserta didik melakukan kegiatan belajar.[8] Sementara itu model pembelajaran adalah suatu perencanaan atau suatu pola yang digunakan sebagai pedoman dalam merencanakan pembelajaran di kelas.

B.R.Hergenhahn menyatakan belajar merupakan perubahan tingkah laku yang terjadi secara permanen sebagai hasil dari pengalaman.[9]

Menurut Piaget. J, pembentukan pengetahuan menurut model konstruktivisme memandang subyek aktif menciptakan struktur-struktur kognitif dalam interaksinya dengan lingkungan. Dengan bantuan struktur kognitifnya ini, subyek menyusun pengertian realitasnya. Interaksi kognitif akan terjadi sejauh realitas tersebut disusun melalui struktur kognitif yang diciptakan oleh subyek itu sendiri. Struktur kognitif senantiasa harus diubah dan disesuaikan berdasarkan tuntutan lingkungan dan organisme yang sedang berubah. Proses penyesuaian diri terjadi secara terus menerus melalui proses rekonstruksi.[10]

Joyce \& Weil mengemukakan bahwa setiap model pembelajaran, selain ada tujuan dan asumsi juga harus memiliki lima unsur karakteristik model, yaitu sintakmatik, sistem sosial, prinsip reaksi, sistem pendukung, dan dampak instruksional dan pengiring.[11] Dewi, Garminah \& Pudjawan pembelajaran berbasis proyek merupakan suatu model yang menekankan siswa untuk dapat belajar secara mandiri dengan memecahkan masalah yang dihadapi serta siswa juga dapat menghasilkan suatu proyek atau karya nyata. Proyek dalam pembelajaran berbasis proyek tidak ditentukan oleh hasil belajar yang didapatkan oleh siswa saja, namun juga dilihat pada proses dan aktivitas siswa dalam proses pembelajaran sehingga akan berdampak pada meningkatnya hasil belajar siswa.[12]

Mulyasa menyatakan modul sebagai paket belajar mandiri yang dirancang secara sistematis untuk membantu peserta didik mencapai tujuan belajar.[13] 
Gunadharma mendefinisikan modul elektronik sebagai sebuah bentuk penyajian bahan belajar mandiri yang disusun secara sistematis ke dalam unit pembelajaran terkecil untuk mencapai tujuan pembelajaran tertentu, yang disajikan dalam format elektronik, di mana setiap kegiatan pembelajaran di dalamnya dihubungkan dengan link-link sebagai navigasi yang membuat peserta didik menjadi lebih interaktif dengan program, dilengkapi dengan penyajian video tutorial, animasi dan audio untuk memperkaya pengalaman belajar.[14]

MOODLE (Modular Object-Oriented Dynamic Learning Environment) adalah paket perangkat lunak yang diproduksi untuk kegiatan belajar berbasis internet dan situs web. Menurut Wicaksono, moodle merupakan salah satu aplikasi dari konsep dan mekanisme belajar mengajar yang memanfaatkan teknologi informasi, yang dikenal dengan konsep pembelajaran elektronik atau E-learning. Moodle dapat digunakan secara bebas sebagai produk sumber terbuka (open source) di bawah lisensi GNU. Moodle dapat diinstal di komputer dan sistem operasi apapun yang bisa menjalankan PHP dan mendukung database SQL.[15]

Heinich, Molenda, \& Russel : "Computer system can delivery instruction by allowing them to interact with the lesson Programmed into the system; this is referred to CAl. CAl adalah suatu sistem penyampaian materi pelajaran yang berbasis mikroprosesor yang dirancang dan diprogram ke dalam sistem tersebut.[16]

Proses pembelajaran administrasi server di kelas XI TKJ 3 di SMK Negeri 3 Singaraja masih mengalami beberapa kendala seperti : terlalu banyak materi yang harus dicari, rumitnya mencari materi dan kurangnya kelengkapan bahan ajar (modul, buku). Pengembangan E-Modul Pada Mata Pelajaran Administrasi Server Kelas XI Teknik Komputer dan Jaringan di SMK Negeri 3 Singaraja ini terdapat beberapa tahapan yaitu : Analyze, Design, Development, Implementation, Evaluation Berdasarkan hal tersebut maka dikembangakan E-Modul Pada Mata Pelajaran Administrasi Server Berbasis Project Based Learning Pada Kelas XI Teknik Komputer dan Jaringan Di SMK Negeri 3 Singaraja.

Penelitian relevan yang digunakan adalah Pengembangan E-Modul Interaktif Sebagai Sumber Belajar Elektronika Dasar Kelas X SMK N 3 Yogyakarta. Hasil penelitiannya menunjukkan 1). Kualitas $E$ modul interaktif sebagai sumber belajar elektronika dasar di SMKN 3 Yogyakarta layak digunakan ditinjau dari: a). Komponen media termasuk kategori sangat layak dengan rerata skor 67,00 dari skor maksimal 80,00 dengan distribusi frekuensi layak dan sangat layak masing-masing sebesar $50 \%$. b). Materi termasuk kategori sangat layak dengan nilai rerata 150,5 dari skor maksimal 160,00 dengan persentase sangat layak 100\%. c). Proses pembelajaran termasuk kategori layak dengan rerata skor 88,12 dari skor maksimal 120,00 dengan persebaran distribusi frekuensi $7,69 \%$, mengatakan "Cukup Layak", 76,92\% "Layak", dan $15,38 \%$ "Sangat Layak". 2). Kelayakan emodul interaktif sebagai sumber belajar elektronika dasar di SMKN 3 Yogyakarta ditinjau dari: a). Tampilan teks, gambar, animasi, ilustrasi dan simulasi termasuk kategori layak dengan skor 23,35 dari skor maksimal 32,00. Rincian dari kelayakan tersebut adalah 11 siswa (36,67\%) mengatakan "sangat layak", 19 siswa $(63,33 \%)$ mengatakakan "layak" . b). Pengoperasian termasuk kategori layak dengan rerata skor 25,62 dari skor maksimal 36,00. Rincian dari kelayakan tersebut adalah 4 siswa $(13,33 \%)$ mengatakan "sangat layak", 19 siswa $(63,33 \%)$ mengatakakan "layak", 7 siswa $(23,33 \%)$ mengatakan "cukup layak". c). Pewarnaan termasuk kategori layak dengan rerata skor 8,27 dari skor maksimal 12,00. Rincian dari kelayakan tersebut adalah 3 siswa $(10,00 \%)$ mengatakan "sangat layak", 26 siswa $(86,63 \%)$ mengatakan "layak", 1 siswa $(3,33 \%)$ mengatakan "cukup layak".

\section{METODE}




\section{A. Jenis Penelitian}

Penelitian ini merupakan jenis Penelitian Pengembangan atau Research and Development (R \& D) yakni metode penelitian yang digunakan untuk menghasilkan produk tertentu, dan menguji kefektifan produk tersebut.

\section{B. Model Pengembangan}

Model yang digunakan dalam penelitian pengembangan ini adalah model ADDIE. Model ADDIE merupakan singkatan dari lima tahapan pada model ADDIE itu sendiri antara lain analyze, design, development, implementation, dan evaluation. Adapun tahapan dalam model ADDIE dapat dilihat pada Gambar 1.

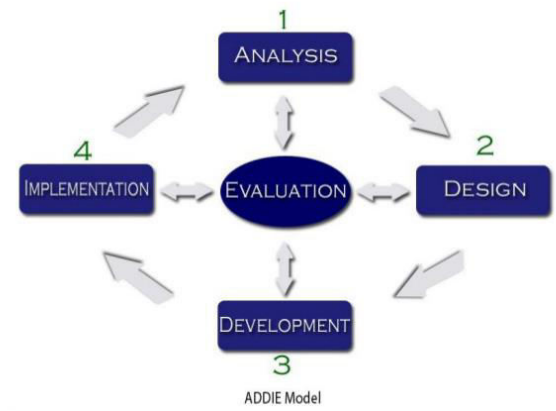

Gambar 1. Langkah Umum Desain Pembelajaran ADDIE

\section{a) Analyze}

Fase analisis merupakan suatu proses yang akan mendefinisikan apa yang akan dipelajari siswa dan masalah guru dalam memberikan materi saat proses belajar dikelas. Pada tahapan ini peneliti melakukan analisis kebutuhan, mengidentifikasi masalah, melakukan analisis tugas. Pengembangan e-modul sangat diperlukan untuk media pembelajaran mengingat media pembelajaran yang ada masih kurang memadai. Analisis kebutuhan untuk menentukan masalah dan solusi yang tepat perlunya pengembangan e-modul pada mata pelajaran Administrasi Server kelas XI Teknik Komputer dan Jaringan di SMK Negeri 3 Singaraja.

Pada tahap analisis, penulis melakukan analisis karakteristik siswa, analisis mata pelajaran, analisis sumber belajar dan analisis tempat penelitian.

\section{b) Design}

Tahap ini yang dilakukan adalah merancang kerangka dari RPP, modul cetak dan e-modul. Modul yang dibuat terstruktur dengan mengikuti tahap model pembelajaran Project Based Learning.

Adapun tahapan desain e-modul yaitu : Desain Rencana Pelaksanaan Pembelajaran (RPP), Desain Modul, Desain E-Modul, Desain Pengembangan E-Modul dan Desain Pengembangan Perangkat Lunak

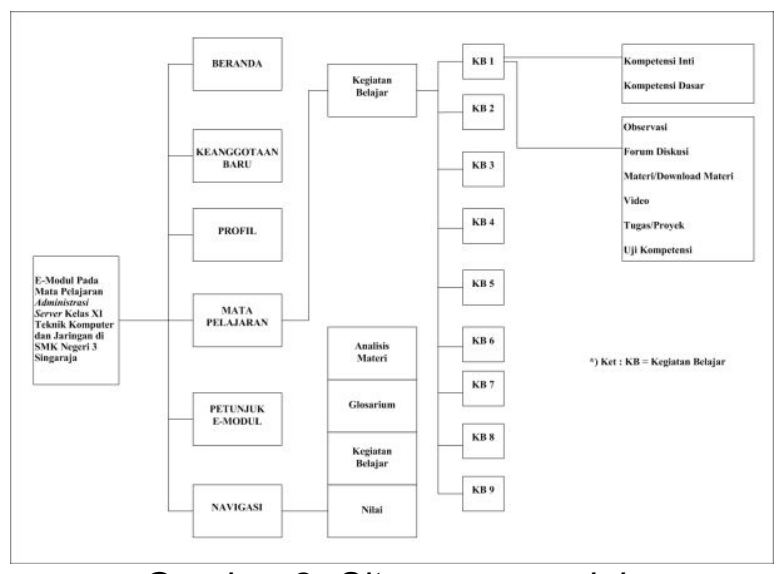

Gambar 2. Sitemap e-modul

\section{c) Development}

Pada fase ini, kegiatan yang dilakukan adalah memproduksi program dan bahan ajar yang akan digunakan dalam e-modul yang diterapkan pada kelas XI program keahlian Teknik Komputer dan Jaringan di SMK Negeri 3 Singaraja. Mengembangkan e-modul sesuai dengan materi dan tujuan yang akan disampaikan dalam pembelajaran, begitu pula dengan lingkungan belajar lain yang akan mendukung proses pembelajaran, semuanya harus disiapkan dalam tahap ini. Sedangkan pada pengembangan perangkat lunak e-modul, mengimplementasikan rancangan sistem yang dibuat dengan menuangkan rancangan tersebut dalam bentuk kode program.

\section{d) Implementation}

Pada fase ini, kegiatan yang dilakukan adalah mengimplementasikan e-modul pembelajaran dengan model Project Based Learning. Tahap implementasi meliputi 
penggunaan e-modul pengembangan untuk diaplikasikan dalam proses pembelajaran Administrasi Server kelas XI yang sudah dirancang sedemikian rupa pada tahap desain.

Tujuan dilakukannya uji coba ini adalah untuk mengetahui kelayakan produk terhadap proses pembelajaran yang dilaksanakan. Pada tahap uji coba ini dilakukan proses evaluasi terhadap emodul yang kembangkan. Proses evaluasi ini dilakukan melalui uji ahli yang meliputi validasi ahli isi, validasi ahli desain, validasi ahli media. Skema Implementasi model ADDIE dapat dilihat pada gambar sebagai berikut.

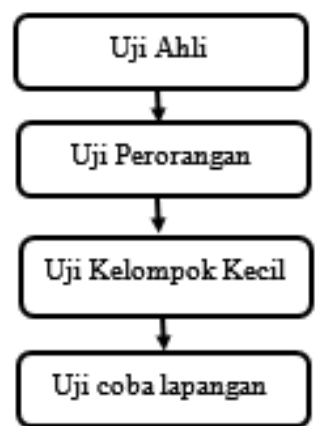

Gambar 3. Skema Implementasi model ADDIE

\section{e) Evaluation}

Pada fase terakhir model ADDIE ini, kegiatan yang dilakukan adalah melakukan evaluasi e-modul pembelajaran. Langkah peneliti pada fase ini adalah mengevaluasi bagian-bagian yang kurang tepat pada emodul ini. Peneliti memeriksa kesesuaian materi dalam e-modul, kesesuaian bahasa yang digunakan dalam e-modul, keterbacaan e-modul, sajian, dan kegrafikan berdasarkan hasil analisis data kuantitatif dan saran dari angket.

\section{Subjek Dan Objek Penelitian}

Subjek penelitian adalah siswa kelas XI Kompetensi Keahlian Teknik Komputer dan Jaringan di SMK Negeri 3 Singaraja. Sedangkan objek dari penelitian ini adalah Pengembangan E-Modul Pada Mata Pelajaran Administrasi Server Berbasis Project Based Learning kelas XI Teknik Komputer dan Jaringan di SMK Negeri 3 Singaraja.

\section{HASIL DAN PEMBAHASAN}

\section{A. Hasil Penelitian}

Hasil penelitian yang telah dilakukan adalah sebuah e-modul mata pelajaran administrasi server yang menggunakan model project based learning. Adapun tampilan dari e-modul yaitu sebagai berikut:

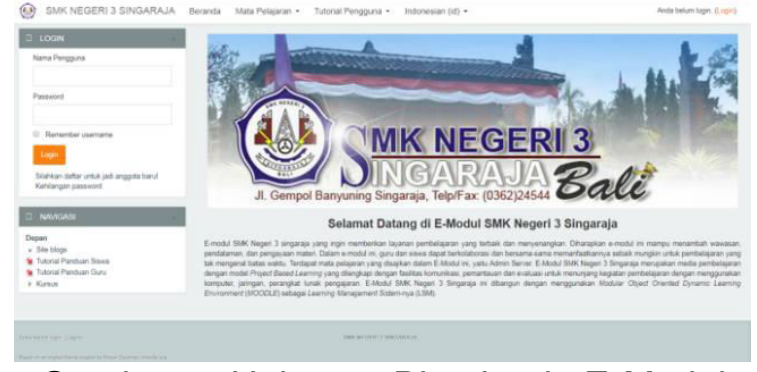

Gambar 4. Halaman Blog Login E-Modul

Pada gambar 4 menunjukkan tampilan login dari e-modul administrasi server SMK Negeri 3 Singaraja. Pada halaman login ini digunakan oleh admin, guru, dan siswa.

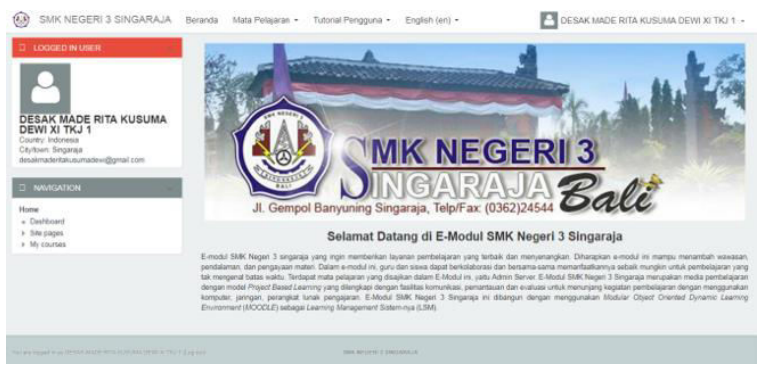

Gambar 5. Halaman Utama Pengguna

Pada gambar 5 menunjukan tampilan awal ketika pengguna berhasil melakukan login. Halaman ini berisi informasi pengantar e-modul dan gambar yang berisi alamat SMK Negeri 3 Singaraja sebagai identitas sekolah.

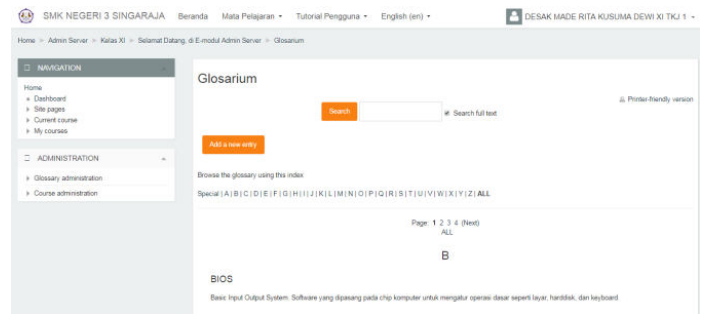

Gambar 6. Halaman Glosarium

Gambar 6 menunjukan tampilan glosarium dari e-modul yang berisikan 
kamus atau kata-kata asing tentang materi yang tersaji dalam e-modul.

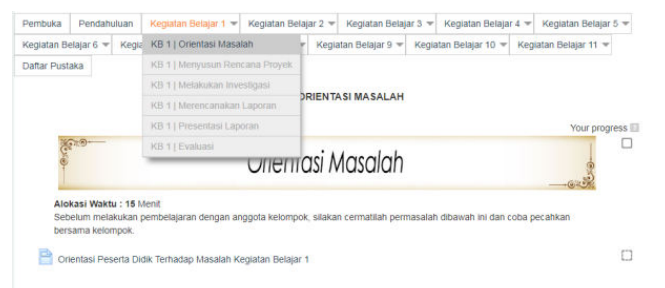

Gambar 7. Halaman Pengembangan Pembelajaran Tuntas

Pada gambar 7 menunjukan halaman pengembangan sistem pembelajaran tuntas sesuai konsep Computer Assisted Instruction (CAI). Siswa wajib menandai (checklist) pada setiap tahapan model project based learning sesuai kegiatan belajar yang sedang diikuti pada e-modul.

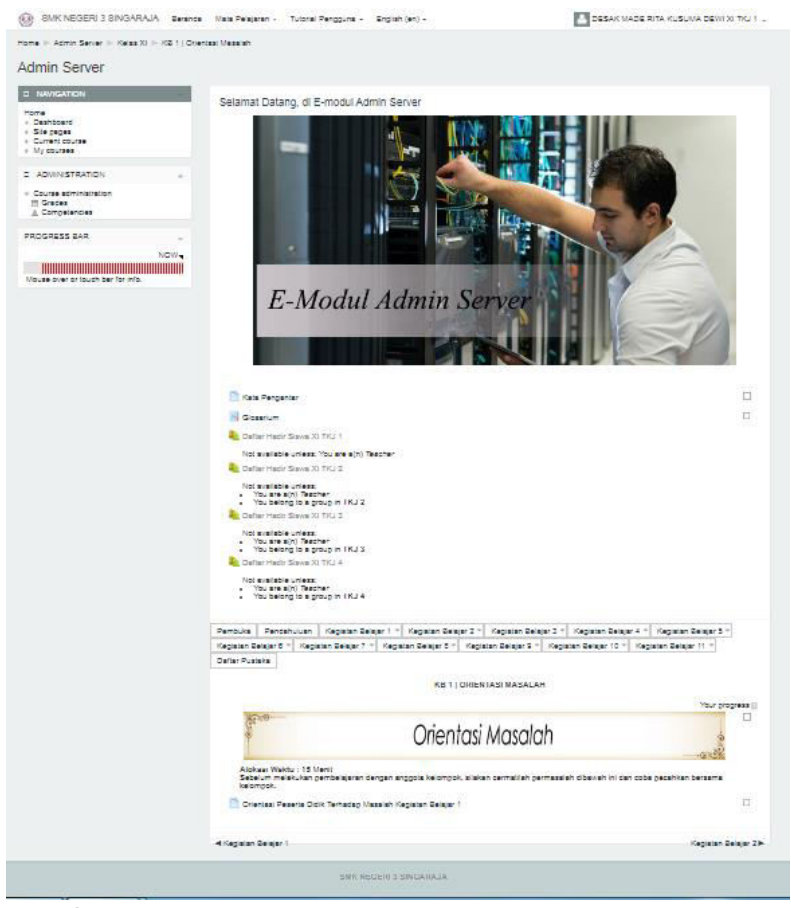

Gambar 8. Halaman Kegiatan Belajar

Pada gambar 8 menunjukan hasil pengembangan halaman kegiatan belajar. Halaman ini berisi materi-materi kegiatan belajar 1 sampai dengan kegiatan belajar 11. Selain materi, dalam halaman kegiatan belajar juga terdapat forum untuk melakukan diskusi dan juga tes formatif.

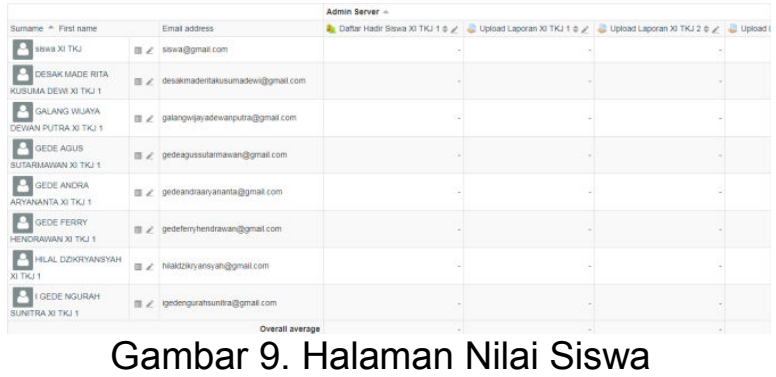

Pada gambar 9 menunjukan halaman nilai siswa. Halaman nilai menampilkan nilai-nilai yang diperoleh siswa dari beberapa penilaian di tahapan pembelajaran project based learning, nilai tugas dan tes formatif.

Sebelum digunakan oleh pengguna maka aplikasi akan diujikan terlebih dahulu untuk memastikan bahwa aplikasi sudah berjalan dengan baik dari awal sampai akhir proses serta tidak terjadi kesalahan. Pengujian yang dilakukan yaitu uji ahli isi, uji ahli design, uji ahli media, uji coba perorangan, uji coba kelompok kecil, uji coba lapangan, uji respon siswa, dan respon guru.

Uji ahli media dilakukan oleh Bapak I Nyoman Meta, S.Pd dan Bapak I Made Ardwi Pradnyana, S.T., M.T. Berdasarkan angket yang disebarkan, hasil penilaian atau tanggapan yang diminta terdiri dari dua pilihan yaitu sesuai dan tidak sesuai. Hasil penilaian ahli isi pembelajaran sudah dinyatakan "SESUAl", namun berdasarkan saran yang diberikan oleh ahli isi maka dilakukan revisi demi kesempurnaan emodul yang dikembangkan. Beberapa masukan yang menjadi revisi produk emodul adalah menambahkan tujuan pembelajaran dan menambahkan kunji jawaban pada evaluasi untuk guru.

Uji ahli media dilakukan oleh Ibu Luh Putu Eka Damayanthi, S.Pd., M. Pd dan Bapak I Gede Mahendra Darmawiguna, S.Kom., M.Sc. Berdasarkan angket yang disebarkan, hasil penilaian atau tanggapan yang diminta terdiri dari dua pilihan yaitu sesuai dan tidak sesuai. Hasil penilaian ahli design pembelajaran sudah dinyatakan "SESUAl", namun saran yang diberikan oleh ahli desain menjadi pertimbangan untuk kesempurnaan e-modul. Revisi yang 
dilakukan pada e-modul yaitu dengan memeriksa kembali penggunaan bahasa dalam penyajian isi materi dalam e-modul secara menyeluruh dan sumber/refrensi agar diperiksa kembali.

Uji ahli media dilakukan oleh Bapak I Made Dendi Maysanjaya, S.Pd., M.Eng dan Bapak P. Wayan Arta Suyasa, S.Pd, M.Pd, hasil penilaian atau tanggapan yang diminta terdiri dari dua pilihan yaitu sesuai dan tidak sesuai. Hasil penilaian ahli desain, produk e-modul memperoleh tingkat pencapaian "SESUAl", namun saran yang diberikan oleh ahli media menjadi pertimbangan untuk kesempurnaan emodul. Adapun masukan yang menjadi revisi produk e-modul dari segi media pembelajaran adalah untuk membedakan tutorial siswa dengan tutorial guru.

Subjek dari uji coba perorangan adalah 3 orang siswa kelas XI Teknik Komputer dan Jaringan yang terdiri atas satu orang dengan prestasi belajar tinggi, satu orang dengan prestasi belajar sedang, dan satu orang dengan prestasi belajar rendah. Berdasarkan angket yang disebarkan, hasil penilaian atau tanggapan yang diminta adalah memberikan skor 1 sampai 5 pada masing-masing pernyataan. Persentase tingkat pencapaian isi e-modul yaitu 87,33 $\%$ berada pada kualifiasi baik.

Uji coba kelompok kecil dilakukan setelah uji coba perorangan. Uji coba kelompok kecil melibatkan 12 orang siswa. Pada uji coba kelompok kecil terhadap emodul administrasi server hasil penilaian yang diminta adalah memberikan skor 1 sampai 5 pada masing-masing penilaian. persentase tingkat pencapaian isi e-modul yaitu $82,08 \%$ berada pada kualifikasi baik.

Uji coba lapangan melibatkan 27 orang siswa untuk menerapkan e-modul administrasi server. Pada uji coba lapangan terhadap e-modul administrasi server hasil penilaian yang diminta adalah memberikan skor 1 sampai 5 pada masing-masing penilaian. Persentase tingkat pencapaian isi e-modul yaitu $83,30 \%$ berada pada kualifikasi baik.

Uji coba respon dilakukan oleh Ibu Nyoman Wahyu Indra Dewi, S.Kom selaku guru mata pelajaran administrasi server di SMK Negeri 3 Singaraja.

Berdasarkan penilaian respon guru terhadap pengembangan e-modul pada mata pelajaran administrasi server, maka dilakukan analisis data menggunakan rumus sebagai berikut.

$$
\bar{x}=\frac{\sum x}{N}=\frac{43}{1}=43
$$

Hasil perhitungan mean ideal (Mi) dan standar deviasi ideal (SDi) adalah sebagai berikut.

$$
\begin{aligned}
& M i=\frac{1}{2}(\text { skor maksimal ideal }+ \text { skor terendah ideal }) \\
& M i=\frac{1}{2}(10+50)=30 \\
& S D i=\frac{1}{6}(\text { skor tertinggi ideal }+ \text { skor terendah idea }) \\
& S D i=\frac{1}{6}(10+50)=10
\end{aligned}
$$

Setelah dikonversikan ke dalam tabel kriteria penggolongan respon, hasil respon guru termasuk dalam rentangan kualifikasi positif. Hal ini menunjukkan bahwa guru antusias dan mendukung dengan adanya pengembangan e-modul mata pelajaran pemrograman dasar. Berdasarkan hasil analisis data respon guru, tidak terdapat masukan ataupun saran yang memerlukan perubahan atau revisi terhadap e-modul.

Uji coba respon siswa melibatkan 27 orang siswa untuk menerapkan e-modul administrasi server. Berdasarkan penilaian respon siswa terhadap pengembangan emodul pada mata pelajaran administrasi server seperti yang dipaparkan pada Lampiran, maka dilakukan perhitungan analisis data respon menggunakan rumus sebagai berikut.

$$
\bar{x}=\frac{\sum x}{N}=\frac{1641}{27}=60,78
$$

Hasil perhitungan mean ideal (Mi) dan standar deviasi ideal (SDi) adalah sebagai berikut. 
$M i=\frac{1}{2}($ skor maksimal ideal + skor terendah ideal $)$

$$
M i=\frac{1}{2}(75+15)=45
$$

$S D i=\frac{1}{6}($ skor tertinggi ideal + skor terendah ideal $)$

$S D i=\frac{1}{6}(75+15)=15$

Setelah di konversikan ke dalam tabel kriteria penggolongan respon, hasil respon siswa dengan rata-rata 60,78 termasuk dalam rentangan kualifikasi positif. Hal ini menunjukkan keberhasilan dalam pengembangan e-modul mata pelajaran administrasi server, yang dibuktikan dengan hasil komentar angket seperti adanya motivasi dan kesenangan siswa menggunakan e-modul serta kemudahan siswa dalam menggunakan e-modul dalam proses pembelajaran.

Berdasarkan hasil analisis data terhadap pengembangan e-modul administrasi server yang berada pada kriteria positif, tidak terdapat masukan ataupun saran dari siswa yang memerlukan perubahan atau revisi terhadap e-modul. Secara garis besar responden merasa senang menggunakan e-modul serta e-modul sudah baik dan membantu dalam pembelajaran administrasi server.

\section{B. Pembahasan}

Hasil penilaian ahli isi berdasarkan angket menunjukkan bahwa tingkat pencapaian dari e-modul adalah "SESUAl" dan layak untuk dilanjutkan. Hal tersebut mengindikasikan bahwa materi pelajaran yang diimplementasikan dalam e-modul sudah relevan untuk digunakan dalam pembelajaran administrasi server. Beberapa masukan yang menjadi revisi produk e-modul dari segi isi pembelajaran seperti melengkapi materi pada kegiatan belajar, telah dilakukan revisi dengan menambahkan tujuan pembelajaran dan menambahkan kunci jawaban pada evaluasi untuk guru.

Hasil penilaian ahli desain pembelajaran terhadap produk pengembangan e-modul yang terdiri dari kelayakan isi, penyajian, tahap pembelajaran model project based learning, dan model pembelajaran sudah dinyatakan "SESUAl" dan layak untuk dilanjutkan. Hal tersebut mengindikasikan bahwa penerapan model pembelajaran project based learning dalam e-modul layak untuk digunakan dalam pembelajaran administrasi server. Masukan ahli desain seperti penggunaan bahasa dalam penyajian isi materi dalam e-modul secara menyeluruh dan sumber/refrensi yang digunakan telah dilakukan revisi melalui pemeriksaan kembali isi e-modul agar emodul valid dari segi desain pembelajaran dan memperbaiki sumber/refrensi dari materi pada e-modul.

Hasil penilaian ahli media pembelajaran yang terdiri dari penggunaan bahasa dan keterbacaan, grafis, desain tampilan emodul, efektivitas, dan media yang dikembangkan dalam e-modul administrasi server telah dinyatakan "SESUAI" dan layak untuk dilanjutkan. Dari evaluasi ahli media, terdapat saran yang diberikan adalah membedakan tutorial siswa dengan tutorial guru telah dilakukan revisi dengan membedakan tutorial siswa dengan tutorial guru.

Langkah selanjutnya yaitu melakukan uji perorangan. Subjek uji perorangan adalah tiga orang siswa kelas XI TKJ3. Dari hasil angket uji coba yang diisi oleh masingmasing siswa, tiga orang siswa memberikan tanggapan baik $(100 \%)$ dan tidak ada siswa yang memberikan tanggapan sangat baik, cukup, kurang, maupun sangat kurang. Rata-rata penilaian siswa adalah $87,33 \%$. Jika dikonversikan ke dalam tabel konversi termasuk dalam kategori baik.

Uji kelompok kecil dilakukan oleh dua belas orang siswa kelas XI TKJ3. Dari hasil angket uji coba kelompok kecil yang diisi oleh masing-masing siswa, terdapat dua belas orang siswa memberikan tanggapan baik $(100 \%)$ dan tidak ada siswa yang memberikan tanggapan sangat baik, cukup, kurang, maupun sangat kurang. Rata-rata penilaian dua belas orang siswa adalah $82,08 \%$. Jika dikonversikan ke dalam tabel konversi termasuk dalam kategori baik. 
Revisi yang sudah dilakukan untuk mengatasi siswa yang belum mengerti pengoperasian e-modul adalah menambahkan tutorial cara penggunaan emodul.

Uji lapangan yang dilakukan oleh dua puluh tujuh orang siswa kelas XI TKJ 1. Dari hasil angket uji coba diperoleh tiga orang siswa memberikan tanggapan sangat baik $(11,11 \%)$, dua puluh empat orang siswa memberikan tanggapan baik $(88,89 \%)$ dan tidak ada siswa yang memberikan tanggapan cukup, kurang, maupun sangat kurang. Rata-rata penilaian keseluruhan responden uji lapangan adalah $83,30 \%$. Jika dikonversikan ke dalam tabel konversi tingkat pencapaian termasuk dalam kategori baik. Berdasarkan temuan di lapangan, penggunaan e-modul dalam proses kegiatan belajar mengajar di kelas dapat membantu siswa memahami materi lebih cepat dan meningkatkan interaksi antar guru dan siswa. Melalui isi materi yang disajikan dalam bentuk teks, tabel dan gambar dalam e-modul siswa lebih mudah memahami materi dan sangat membantu dalam pengerjaan proyek. Keberhasilan model pembelajaran project based learning untuk meningkatkan aktivitas belajar siswa disebabkan oleh penerapan model project based learning yang membantu siswa terlibat secara aktif mengikuti pembelajaran. Model project based learning memberikan kesempatan siswa untuk belajar menyenangkan, sehingga menumbuhkan minat siswa untuk belajar dan mendorong siswa untuk mengembangkan keterampilannya.

Uji respon guru dilakukan oleh satu orang responden yaitu Ibu Nyoman Wahyu Indra Dewi, S.Kom dan memperoleh ratarata sebesar 43, jika dikonversikan ke dalam tabel kriteria penggolongan respon maka hasilnya termasuk dalam kategori positif. Proses uji selanjutnya dilakukan dengan pengambilan respon siswa. Subjek uji coba respon siswa adalah terdiri dari dua puluh tujuh orang siswa kelas XI TKJ1 yang telah belajar menggunakan e-modul. Hasil angket respon siswa terhadap pengembangan e-modul administrasi server memperoleh rata-rata sebesar 60,78 , jika dikonversikan ke dalam tabel kriteria penggolongan respon maka hasilnya termasuk dalam kategori positif. Berdasarkan hasil respon guru dan siswa dapat dikategorikan membantu siswa dalam memahami mata pelajaran administrasi server dan berhasil mengatasi permasalahan tidak adanya modul ajar.

Hasil penelitian e-modul berbantuan media CAl pada mata pelajaran administrasi server ini sejalan dengan penelitian Menurut Fausih, $M$ tentang Pengembangan Media E-Modul Mata Pelajaran Produktif Pokok Bahasan "Instalasi Jaringan Lan (Local Area Network)" Untuk Siswa Kelas XI Jurusan Teknik Komputer Jaringan Di Smk Negeri 1 Labangbangkalan Madura. Teknik pengumpulan data dari ahli materi dan ahli media menggunakan teknik wawancara, sedangkan untuk siswa menggunakan angket dan tes. Hasil wawancara dari ahli materi dan ahli media digunakan sebagai acuan untuk merevisi produk, sedangkan hasil tes untuk mengetahui hasil belajar siswa setelah menggunakan e-Modul. Berdasarkan hasil tahapan uji coba kelompok besar, yakni uji coba pada siswa kelas XI jurusan teknik komputer jaringan diperoleh data $\mathrm{t}$ hitung lebih besar dari $\mathrm{t}$ tabel yakni $2,499>2,042$. Maka dapat disimpulkan bahwa e-Modul Produktif "Instalasi Jaringan LAN" termasuk kategori efektif karena dapat meningkatkan hasil belajar siswa.[17] Dari segi desain pengembangan Moodle, keterbacaan, dan keefektifan produk, e-learning dengan Moodle yang dikembangkan Putra, Suwatra, \& Suartama mampu meningkatkan hasil belajar siswa. Dalam elearning berbasis Moodle, kegiatan pembelajaran disusun secara sistematis dilengkapi dengan forum diskusi, materi beserta contoh-contoh berupa video dan gambar yang menarik, dan penugasan/quis agar siswa lebih termotivasi untuk belajar. Hal ini juga diterapkan pada e-modul fotografi yang dikembangkan dengan Moodle, desain pembelajaran disajikan semenarik mungkin, fitur pembelajaran 
disajikan dengan jelas dan lengkap, penggunaan huruf dan media disajikan dengan rapi dan mudah dipahami.[18]

Sudarma tentang Pengembangan EModul Dengan Model Problem Based Learning Mata Pelajaran Pemrograman Dasar Kelas XI Teknik Komputer dan Jaringan di SMK Negeri 3 Singaraja. Hasilnya secara garis besar pengembangan e-modul pemrograman dasar layak untuk digunakan. Hal ini dapat dibuktikan melalui hasil dari pengujian yang dilakukan oleh ahli isi, ahli desain pembelajaran dan ahli media. Hasil penilaian dari para ahli berdasarkan angket sudah dinyatakan "SANGAT BAIK", maupun hasil respon guru dan siswa termasuk dalam kategori baik dan mendapat respon SANGAT POSITIF. Butirbutir instrument positif yang membantu peneliti untuk pengujian respon siswa yaitu 1) Saya merasa senang menggunakan emodul dalam proses pembelajaran pemrograman dasar karena berisi materi yang jelas dan lengkap. 2) Materi di dalam e-modul pemrograman dasar mudah dipahami. 3) Tahap pembelajaran model problem based learning pada e-modul pemrograman dasar membuat saya lebih aktif dalam belajar. Berdasarkan rekapitulasi penilaian dari masing-masing responden pada uji lapangan, memperlihatkan bahwa penilaian yang diberikan oleh siswa adalah 63,33\% Sangat Baik, 36,67\% Baik, 0\% Cukup, 0\% Kurang, dan 0\% Sangat Kurang. Rata-rata persentase dari keseluruhan subyek adalah $90,3 \%$. Jika dikonversikan kedalam tabel konversi termasuk dalam kategori sangat baik dan tidak perlu direvisi.[19]

Ariasa tentang Pengembangan E-Modul Berbantuan Media CAI Pada Mata Pelajaran Fotografi X Desain Komunikasi Visual di SMK Negeri 1 Sukasada menggunakan tahapan model project based learning sudah dinyatakan berhasil diterapkan. Hal ini dapat dilihat dari ratarata persentase berdasarkan hasil pengujian yang telah dilakukan. Secara umum siswa terlihat antusias dan lebih aktif selama proses pembelajaran berlangsung.
Respon guru terhadap pengembangan emodul berbantuan media CAl pada mata pelajaran fotografi kelas $X$ Desain Komunikasi Visual di SMK Negeri 1 Sukasada didapatkan rata-rata sebesar 47 . Jika dikonversikan ke dalam tabel kriteria penggolongan respon maka hasilnya termasuk dalam kategori sangat positif. Sedangkan untuk respon siswa terhadap pengembangan e-modul fotografi memperoleh rata-rata sebesar 67,79. Jika dikonversikan ke dalam tabel kriteria penggolongan respon maka hasilnya termasuk dalam kategori sangat positif. [20]

Sugihartini tentang Pengembangan EModul Pada Mata Kuliah Strategi Pembelajaran sebagai salah satu inovasi dalam perkuliahan, telah diimplementasikan pada web elearning undiksha dengan alamat http://elearning.undiksha.ac.id. Emodul yang dikembangkan dalam penelitian ini berbasis CAl (computer assisted instruction) yang artinya jika mahasiswa belum menyelesaikan satu kegiatan belajar, maka kegiatan belajar berikutnya diinvisible oleh sistem. Setiap kegiatan belajar dikemas dengan mengikuti sintak proses pembelajaran project based learning. Tahap penelitian berikutnya yang dilakukan adalah melakukan pengujian sistem e-modul ke beberapa judges, diantaranya ahli isi, media dan design pembelajaran.[21]

Berdasarkan pembahasan di atas, penilaian-penilaian yang dilakukan oleh ahli isi, ahli desain pembelajaran, ahli media, uji coba perorangan, uji coba kelompok kecil, uji lapangan, maupun hasil respon guru dan siswa termasuk dalam kategori baik dan mendapat respon positif. Berdasarkan penilaian tersebut, secara garis besar pengembangan e-modul pada mata pelajaran administrasi server berbasis project based learning telah menunjukkan adanya keberhasilan dan layak digunakan sebagai sumber belajar untuk siswa kelas XI TKJ di SMK Negeri 3 Singaraja. Hal ini didukung pula dengan beberapa pernyataan siswa yaitu keberadaan emodul administrasi server sangat membantu dalam proses pembelajaran, e- 
modul membuat siswa lebih antusias dalam belajar administrasi server, maupun memudahkan siswa memahami materi lebih cepat dan sangat efektif dalam pelajaran. Melalui penerapan e-modul administrasi server ini diharapkan dapat membantu guru selama proses pembelajaran dan masalah selama proses pembelajaran terkait sumber belajar mampu teratasi, intensitas belajar siswa meningkat, dan membantu siswa menjadi lebih aktif dalam proses belajar mengajar secara mandiri maupun berkelompok.

\section{SIMPULAN}

Berdasarkan hasil penelitian dan pembahasan pada penelitian pengembangan e-modul pada mata pelajaran administrasi server berbasis project based learning, maka penulis dapat menarik kesimpulan sebagai berikut.

1. Hasil rancangan dan implementasi pengembangan e-modul pada mata pelajaran administrasi server berbasis project based learning kelas XI Teknik Komputer dan Jaringan di SMK Negeri 3 Singaraja dinyatakan berhasil diterapkan. Hal ini dapat dilihat dari rata-rata persentase berdasarkan hasil pengujian yang telah dilakukan. Secara umum siswa terlihat antusias dan lebih aktif selama proses pembelajaran berlangsung.

2. Respon guru terhadap pengembangan e-modul pada mata pelajaran administrasi server berbasis project based learning kelas XI Teknik Komputer dan Jaringan di SMK Negeri 3 Singaraja didapatkan rata-rata sebesar 43. Jika dikonversikan ke dalam tabel kriteria penggolongan respon maka hasilnya termasuk dalam kategori positif. Sedangkan untuk respon siswa terhadap pengembangan e-modul administrasi server memperoleh rata-rata sebesar 60,78. Jika dikonversikan ke dalam tabel kriteria penggolongan respon maka hasilnya termasuk dalam kategori positif.

\section{REFERENSI}

[1] National Centre For Competency Based Training 2007. Pengertian Bahan Ajar.

[2] Santyasa, I. (2009). Metode Penelitian Pengembangan dan Teori Pengembangan Modul

[3] Adiputra, I N S. (2014). Pengembangan E-Modul pada Materi "Melakukan Instalasi Sistem Operasi Jaringan Berbasis GUI dan Text" untuk Siswa Kelas X Teknik Komputer dan Jaringan SMK Negeri 3 Singaraja. Pendidikan Teknik Informatika, Universitas Pendidikan Ganesha. JANAPATI 1-7

[4] Adnyana, I. P. (2014). Pengembangan Modul Ajar Melakukan Instalasi Perangkat Jaringan Lokal Untuk Siswa Kelas XI Program Keahlian Teknik Komputer Dan Jaringan (TKJ) Di Smk Negeri 3 Tabanan.

[5] Jonias. (2014). Pengembangan Media Pembelajaran E-Module Terhadap Prestasi Belajar Siswa Dalam Mata Pelajaran Muatan Lokal Elektronika Di SMPN 6 Surabaya. Pendidikan Teknik Elektro, Fakultas Teknik, Universitas Negeri Surabaya, 645-649.

[6] Satriawati, H. (2015). Pengembangan E-Modul Interaktif Sebagai Sumber Belajar Elektronika Dasar Kelas X SMK N 3 Yogyakarta. Thesis. UNY http://eprints.uny.ac.id/id/eprint/19128.

[7] Poppy Kamalia Devi, d. (2009). Pengembangan Perangkat Pembelajaran untuk Guru SMP. Bandung: PPPPTK IPA.

[8] Sugihartono. (2007). Psikologi Pendidikan. Jogjakarta: Universitas Negeri Yogyakarta.

[9] B.R.Hergenhahn, M. H. (2010). Theories of Learning / Teori Belajar. Jakarta: Kencana Prenada Media Grup.

[10] Piaget.J. (1988). Antara Tindakan dan Pikiran (Terjemahan Agus Cremes). Jakarta: PT.Rineka Cipta.

[11] Joice, B., \& Weil, M. (2000). Models of Teaching. New Jersey: Pentince-Hal Inc.

[12] Dewi, A., Garminah, \& Pudjawan. (2013). Pengaruh Model Pembelajaran 
Berbasis Proyek (Project-Based Learning) terhadap Hasil Belajar IPA Siswa Kelas IV SDN 8 Banyuning.

[13] Mulyasa, E. 2. (2005). Menjadi Guru Profesional. Bandung: PT Remaja Rosdakarya.

[14] Gunadharma, A. (2011). Pengembangan Modul Elektronik Sebagai Sumber Belajar Untuk Mata Kuliah Multimedia Design. Jurusan Teknologi Pendidikan, Fakultas IImu Pendidikan, Universitas Negeri Jakarta. Skripsi (tidak diterbitkan) .

[15] Wicaksono, W. (2015). Perancangan Dan Implementasi E-Learning Pendukung Project Based Learning. http://s3.amazonaws.com/academia.ed u.documents/37179169/S52_CAMRED -Perancangan_Dan_Implementasi_E.

[16] Heinich, R., Molenda, \& Russel, J. D. (2002). Instructional media and technology for learning, 7th edition. New Jersey: Pretince Hall, Inc.

[17] Fausih, M., \& Tandyonomanu, D. (2015). Pengembangan Media EModul Mata Pelajaran Produktif Pokok Bahasan "Instalasi Jaringan LAN(Local Area Network)" Untuk Siswa Kelas XI Jurusan Teknik Komputer Jaringan Di SMK Negeri 1 Labang Bangkalan Madura. Jurnal Online Universitas Negeri Surabaya, 1-9.

[18] Putra, P. G., Suwatra, I W., \& Suartama, I K. (2015). Pengembangan E-Learning Berbasis Moodle Pada Mata Pelajaran IPS Kelas VIII Di SMPN 1 Selemadeg. e-Journal Edutech Universitas Pendidikan Ganesha.

[19] Sudarma, I G., Resika Arthana, I K., \& Partha Sindu, I G. (2016). Pengembangan E-Modul Dengan Model Problem Based Learning Mata Pelajaran Pemrograman Dasar Kelas XI Teknik Komputer dan Jaringan di SMK Negeri 3 Singaraja. Kumpulan Artikel Mahasiswa Pendidikan Teknik Informatika (KARMAPATI).

[20] Ariasa., Saindra Santyadiputra, G., Partha Sindu, I G. (2016). Pengembangan E-Modul Berbantuan
Media CAl Pada Mata Pelajaran Fotografi $X$ Desain Komunikasi Visual di SMK Negeri 1 Sukasada. Jurnal Nasional Pendidikan Teknik Informatika (JANAPATI)

[21] Sugihartini, N. (2017). Pengembangan E-Modul Mata Kuliah Strategi Pembelajaran. Jurnal Pendidikan Teknoogi dan Kejuruan.

[22] Putra, K. W. B., Wirawan, I. M. A., \& Pradnyana, G. A. (2017). Pengembangan E-Modul Berbasis Model Pembelajaran Discovery Learning Pada Mata Pelajaran "Sistem Komputer" Untuk Siswa Kelas X Multimedia SMK Negeri 3 Singaraja. Jurnal Pendidikan Teknologi dan Kejuruan, 14(1). 